IRA-International Journal of Management \& Social Sciences

ISSN 2455-2267; Vol.14, Issue 01 (January, 2019)

Pg. no. 14-19.

Institute of Research Advances

http://research-advances.org/index.php/RAJMSS

Institute of

\title{
The Role of TASK, A Bridge between Higher Education Institutes and Industries, in Enhancing the Employment Opportunities of Students in the State of Telangana, India
}

\author{
Dr M. Pratibha \\ Professor-English \& HoD-Humanities and Sciences, Mahaveer Institute of Science and \\ Technology, Hyderabad, India.
}

Type of Review: Peer Reviewed.

DOl: http://dx.doi.org/10.21013/jmss.v14.n1.p3

How to cite this paper:
Pratibha, M. (2019). The Role of TASK, A Bridge between Higher Education Institutes and
Industries, in Enhancing the Employment Opportunities of Students in the State of Telangana,
India. IRA-International Journal of Management \& Social Sciences (ISSN 2455-2267), 14(1), 14-19.
doi:http://dx.doi.org/10.21013/jmss.V14.n1.p3

(C) Institute of Research Advances.

\section{(cc) Br-no}

This work is licensed under a Creative Commons Attribution-Non Commercial 4.0 International License subject to a proper citation to the publication source of the work.

Disclaimer: The scholarly papers as reviewed and published by the Institute of Research Advances (IRA) are the views and opinions of their respective authors and are not the views or opinions of the IRA. The IRA disclaims of any harm or loss caused due to the published content to any party.

Institute of Research Advances is an institutional publisher member of Publishers International Linking Association Inc. (PILA-CrossRef), USA. The institute is an institutional signatory to the Budapest Open Access Initiative, Hungary advocating the open access of scientific and scholarly knowledge. The Institute is a registered content provider under Open Access Initiative Protocol for Metadata Harvesting (OAI-PMH).

The journal is indexed \& included in WorldCat Discovery Service (USA), CrossRef Metadata Search (USA), WorldCat (USA), OCLC (USA), Open J-Gate (India), EZB (Germany) Scilit (Switzerland), Airiti (China), Bielefeld Academic Search Engine (BASE) of Bielefeld University, Germany, PKP Index of Simon Fraser University, Canada. 


\begin{abstract}
The present study is an endeavour to have some insights into TASK's activities and to provide possible suggestions to reduce the present gap between HEIs and industry. TASK has been introduced in the fouryear-old state of Telangana to find the need to promote academic freedom in producing skilled professionals. In the process of developing innovative schemes to fill the gap between HEIs (Higher Education Institutes) and industries, the state of Telangana, India, has started TASK (Telangana Association for Skill and Knowledge) in the year 2015. TASK is a non-profit organization with an objective of offering quality human resources and services to the industry at subsidized rates. Courses are created by experts according to the requirements of the industry. These courses are focused to create skilled professionals who can contribute to the industry. For example, when Samsung needed employees trained in Tizen programming, TASK could train and supply the required immediately. TASK enables graduate retention (by avoiding brain drain particularly to the developed countries) and quality attractiveness of local employment.
\end{abstract}

Keywords: TASK, higher education, employment, Employability Quotient, etc.

\title{
1. Introduction
}

Higher education institutions should "develop innovative schemes of collaboration between institutions of higher education and different sectors of society to ensure that higher education and research programmes effectively contribute to local, regional and national development" (UNESCO, 1998). Innovative schemes are necessary to meet the changing demands for specific required skills from the industry. To achieve this, it is necessary to have collaboration between higher education institutes and industry, which is not so easy. Certain schemes are necessary to act as a bridge between industry and higher education institutes.

The Indian higher education system is facing an unprecedented transformation in the coming decade (British Council, 2014). The increasing population, the developing economy, and the changing needs of people lead to a high demand on the education system, particularly the higher education system. Higher education should, where it is possible, perform the function of preparing at least some of its graduates for employment (West, 2000). In the process of preparation for employment, employer's needs have to be satisfied. This is possible by updating the syllabus of higher education and it is a time-consuming process. Thus, a linking source is essential to meet time-totime changing needs of industry.

Over the last decade, there is increasing emphasis on the development of a knowledge-based economy in order to boost competitiveness on world markets. Higher education institutions have been acknowledged as major players in this process (Hedin, 2009). Immediately after their higher education, students are entering into the employment market. Thus, the higher education institutions are acting as the fore-runners of the employment opportunities.

Demand for courses from mature learners and from current students looking to enhance their employability and develop entrepreneurial skills are creating new markets and new requirements for HE (Higher Education) institutions as well as support for a national qualifications framework. There is little capacity at present in universities for teaching either skill for employability or entrepreneurship (British Council, 2014). Thus, a link is necessary between HEIs and industry. Low levels of industry engagement (British Council, 2014) demand for more skill-based jobs. The services sector saw a large growth in terms of numbers and also the variety of jobs. A new type of jobs emerged that did not exist a generation ago (FICCI, 2016). New types of jobs demand new skills. These new skills vary from time-to-time. Thus, it is necessary to have university-industry links to meet the timely requirements of the industry.

The education sector is feeling the impact of these changes - there is an increasing demand for corporate training services, which cater to the reskilling and upskilling needs of working professionals (FICCI, 2016). In the state of Telangana, TASK is playing various roles to link-up universities and industry.

The objectives of the present study are:

- to have some insights TASK's activities and

- to provide possible suggestions to reduce the present gap between HEIs and industry 


\section{TASK}

About the TASK, TASK's agenda, employment quotient, Value for students, colleges and corporates have been elaborated in the following lines.

\subsection{About TASK}

TASK is a non-profit organization created by the Government of Telangana for making a loop among institutions of Government, Industry and Academia with an objective of offering quality human resources and services to the industry. TASK is granting access to modules for improving their technological, personal and organisational skills at highly subsidized rates. TASK promotes partnerships with colleges to create environs conducive for growth through faculty development, research pilots and help colleges provide quality education for the leaders of tomorrow with focused systematic Programme. TASK programmes help corporates gain access to a stream of trained graduates for suitable roles. Students are trained extensively in the latest technology to help companies find the right candidate. TASK skill offerings are for engineering, degree, MBA, MCA, polytechnic and faculty. All the training are available online for enrollment (TASK, 2018).

\subsection{TASK's agenda}

TASK's agenda includes: education, entrepreneurship and employability

TASK's claim: "For the education sector, it provides career guidance to select the right university. TASK provides a virtual platform through mobile - MOOCs-Massive Open Online Courses. This operates through aptitude and training, students go through the modules and evaluated through an online assessment test".

Findings: Under career guidance, FDP (Faculty Development Programme) for faculty and industry visit for students are popular.

MOOCS online courses are for four months focusing on computer and communication skills. At the end of the course, an appreciation letter is issued. MOOCS qualified students of TASK are preferred over the other certifications.

TASK's claim: "TASK provides technical training in collaboration (MoUs) with corporate-like Oracle, IBM, SAP, CISCO, and offering emerging technologies like Big data, Networking essentials, data analytics, Cloud computing, etc. to students."

Findings: Required software training for 'Software Developer' is given for the technical students of CSE, ECE and IT branches of engineering.

TASK's claim: “'Tizen' operating system by Samsung reduces training cost and in turn, mobile cost. Samsung entered with its own operating system (Tizen) and implementing in all Smart devices such as washing machines, refrigerators - IOTs - Internet of Things (TASK, 2018)."

Findings: For example, when Samsung needed employees trained in Tizen programming, TASK could train and supply the required immediately.

\subsection{Employability quotient}

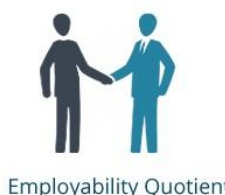

Employability Quotient
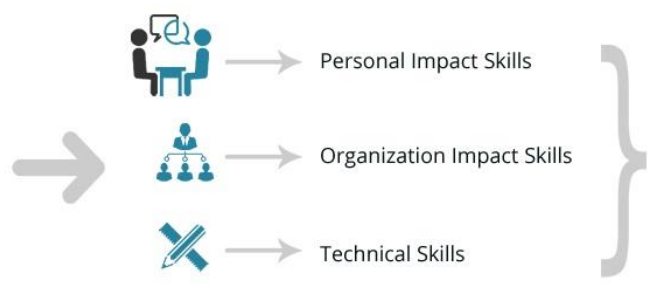
Fig.1: Employability quotient (Source: https://www.task.telangana.gov.in/)

TASK is providing training to develop the skills of individuals. Increased employable skills have a direct effect on employability ("the skills and abilities that allow you to be employed" Cambridge, 2018), entrepreneurship and higher education (Fig.1).

\subsection{Multiple benefits of TASK}

Varied benefits of TASK are mentioned for student, institutes and corporate in the following lines.

\subsubsection{Benefits for students}

Students benefit range from orientation to soft skills, access to various courses, internships, finishing schools, placement drives, etc.

- Access to various skill courses in collaboration with Global Technology Organizations like Oracle, Salesforce, IBM, Samsung, Autodesk, SAP etc.

- Orientation on Soft Skills by industry professionals

- Access to Internships, Industry visits

- Access to e-learning modules on varied topics - E.g. Aptitude \& Reasoning, English, Technical \& Soft Skill Concepts

- Opportunity to take part in placement drives of various companies

- Exposure to Entrepreneurship Development Programs

- Participation in various competitions online practice tests

- Career Planning Workshops and Finishing Schools

(TASK, 2018)

TASK facilitates internships to meritorious students, who are selected through the written test, in various industries. e-learning modules on varied topics - E.g. Aptitude \& Reasoning, English, Technical \& Soft Skill Concepts are provided for 15- 20 hours each.

\subsubsection{Benefits for colleges}

Colleges act as a venue for various events. Colleges are also linked up to the industry through TASK.

- Industry Relevant Faculty Development Programs

- College Specific Skill Pilots with Industry/Government

(TASK, 2018)

\subsubsection{Benefits for corporates}

The work of corporate becomes much easier through TASK.

- Access to a pool of trained graduates for internships and placements

- Forum to connect with the government and share inputs for the overall development of the state

(TASK, 2018)

\subsection{Finishing school}

With a view to meet the shortage of skilled human resource requirements of corporates, TASK has taken up the initiative to conceive and roll out Finishing School Pilots for students who have completed their graduation and are currently unemployed with an objective of enhancing their Employability Quotient.

TASK registration happens only when the candidates are students of a college. However, validity is for four years after college. Students have been accepted the role of TASK.

\section{Discussion}

TASK (Telangana Association for Skill and Knowledge) imparts training to students, which will help them to be industry ready and get placements. TASK has a well-defined training programme which has a span of a complete academic course, which is meant for B.Tech. second year to final year. 
The training program imparted by TASK fulfills the gap between industry and academia. For example, certain topics which are not covered in the syllabus of B.Tech., are compensated through TASK, which will enhance skills of the students, which in turn, will help them to be more marketable personal, organizational and technical skills.

The growing preference of students toward liberal arts programs also highlights the fact that learners are looking at the breadth of learning than just in-depth technical knowledge in one subject. Many universities have reworked their curriculum to adopt Choice Based Credit System (CBCS) to offer the flexibility in learning to the students - so that the students of today have better adaptability toward the jobs of the future (FICCI, 2016).

All institution types utilise private institutions for links with industries (British Council, 2014).

In Hedin's (2009) study higher education institutes are "knowledge bridges" that higher education institutions can play a considerable role in respect of regional development. There is a connection to entrepreneurship in the region. For example, collaboration with other higher education institutions within the country and abroad implies improved access to relevant knowledge of use to companies in the region.

Higher education institutions have a role to play concerning regional development. By offering education to the workforce that matches the needs of both private and public employers in the region their regional impact may be enhanced. However, this offering must be dynamic since needs are constantly changing (Hedin, 2009). There are a number of tasks national governments could undertake to enhance the response of higher education institutions to regional needs, for example, which courses are taught where, what the home origins of students are, and where do graduates enter the labour market. (Goddard 2011). TASK is considering the regional needs by providing soft skills training, language training, technical skills, etc. which are readily employable.

Governments can establish incentives and funding programmes to encourage higher education institutions to establish programmes or projects with an explicit regional dimension (Chatterton \& Goddard, 2000). TASK is for catering the employability needs at the regional level. This is a role model for the other regional states as well.

An increasing number of private sector organizations have realized that it is the employability of the candidates that matters, not their qualifications when it comes to real business (Kapai, 2009). It has been confirmed through a number of ways. Thus, it is necessary to increase the qualities of employability skills. This can be done by including the required content in the curriculum or providing the additional courses.

There should be a symbiotic relationship between universities and industries. The mutual co-operation, in turn, results in saving resources and time, apart from boosting the confidence of young students. The university curriculum should be designed as per the requirements of industries.

To reduce brain-drain and convert to brain-gain by improving the required skills of students, thus, skilled candidates would naturally attract the local job markets.

Universities in collaboration with industries should have a comprehensive and strategic plan on a priority basis to mobilize state-level grants. Part of these grants should be utilized for skill development programs. Funding can also be channelized through charitable donations. Government policies should be need-specific depending on the state's challenges. State and central level co-operation is essential in the policy-making process. TASK activities should be evaluated from time-to-time with regard to students, universities and industries.

\section{Conclusion}

Though at present TASK could not provide immediate employment to all its trained professionals, gradually it will reach the desired goal by following stated possibilities. Stronger efforts are necessary for the all-round development of graduates. Apart from the technical skills; it is essential to have subject knowledge, communication skills, personality aspects, language skills, team spirit and utilization of learned skills. Districts with more HEIs and programs like Tizen experienced faster employment. TASK's role is unique in the state since it is fulfilling the immediate and future needs of industry by readily supplying trained graduates. Soon this would grab the attention of a number of industries to the state, thus, enhancing the employment opportunities. 
Much more needs to be done to nurture the next generation of Indian researchers, through providing: early-stage research experience and international networking; analysis and problem-solving skills; English for researchers; proposal and bid writing training; bilateral research student exchanges and international research student workshops and conferences (British Council, 2014).

\section{References}

[1]. British Council, 2014: Understanding India: The future of higher education and opportunities for international cooperation, February 2014 https://www.britishcouncil.in/sites/default/files/understanding_india.pdf

[2]. Cambridge, 2018: https://dictionary.cambridge.org/dictionary/english/employability, Retrieved on 10.05.2018

[3]. Chatterton Paul \& Goddard John, 2000: The Response of Higher Education Institutions to Regional Needs European Journal of Education, Vol. 35, No. 4, 2000

[4]. FICCI, Federation of Indian Chambers of Commerce and Industry 2016: Future of Jobs and its imperatives on Indian Higher Education, November 2016. http://www.ficci.in/spdocument/20787/FICCI-Indian-HigherEducation.pdf

[5]. Goddard John, 2011: Connecting Universities to Regional Growth: A Practical Guide, European Union regional policy, European Journal of Education, Blackwell

[6]. Hedin Sigrid (editor), 2009 Higher education institutions as drivers of regional development in the Nordic countries, Nordregio Working Paper 2009:3 ISSN 1403-2511, Stockholm, Sweden 2009 Nordregio WP 2009:3

[7]. Kapai Neeta, 2009: Raising the employability quotient of a geographically dispersed learner population through a flexible and modular employable skills training curriculum, IGNOU, India, M-2009

[8]. Paytas, 2004: Universities and the Development of Industry Clusters Jerry Paytas, Ph.D., Robert Gradeck and Lena Andrews. 2004 Prepared for Economic Development Administration U.S. Department of Commerce

[9]. TASK, 2018: https://www.task.telangana.gov.in, Retrieved on 19.03.2018

[10]. UNESCO, 1998: A Framework for Priority Action for Change and Development in Higher Education (Paris, UNESCO).

[11]. West John, 2000: Higher Education and Employment: opportunities and limitations in the formation of skills in a mass higher education system, Journal of Vocational Education and Training, Volume 52, Number 4, 2000. 